\title{
Isolation and Transduction Analysis of Temperature-sensitive Mutants of Staphylococcus aureus Defective in DNA Replication
}

\author{
By C. M. THOMAS AND K. G. H. DYKE \\ Microbiology Unit, Department of Biochemistry, South Parks Road, \\ Oxford, $O X 13 Q U$
}

(Received 10 October 1977)

Four temperature-sensitive mutants of Staphylococcus aureus with defects affecting DNA
synthesis have been isolated and partially characterized. They fall into two groups: three
have defects either in elongation of DNA or synthesis of its precursors; the fourth has
properties inconsistent with a defect in either elongation or initiation. Transduction analysis
indicated that the mutation in this fourth mutant is unlinked to the mutations in the other
three, which are all clustered on one side of a gene conferring resistance to novobiocin.

\section{INTRODUCTION}

Studies of DNA replication in Staphylococcus aureus have been largely confined to investigation of the biochemistry and genetics of plasmid replication. Mutants with defects in both plasmid and chromosomal genes specific for plasmid replication have been isolated (Novick, 1967, 1974) and partially characterized (Novick et al., 1974). The dependence of plasmid replication on genes also involved in chromosome replication and the nature of genes involved in chromosome but not plasmid replication have not, however, been studied in detail. Measures (1973) isolated a number of temperature-sensitive dna mutants in S. aureus Ps 80 and Raftery (1974) partially characterized one of these, whose properties indicated a defect in initiation. None of these defects could be suppressed by the presence of the plasmid $\mathrm{pI}_{9789}$ and, in the initiation mutant, plasmid replication was affected more rapidly than chromosome replication when the bacteria were placed at the restrictive temperature. The mutants were not, however, fully characterized nor were the mutations mapped. It was thus impossible to estimate the number of genetic loci affected by these defects.

In work designed to investigate these questions more thoroughly in S. aureus NCTC 8325 , temperature-sensitive mutants with defects in chromosome replication have been isolated and characterized. In this paper the isolation and transduction analysis of four such mutants are described.

\section{METHODS}

Bacteria. Staphylococcus aureus NCTC 8325 and derived strains were used. $8325 \mathrm{Nov}^{\mathbf{R}}$ was isolated after ethyl methanesulphonate (EMS) mutagenesis by selection with novobiocin on CY agar by a disc diffusion method $\left(2 \mu \mathrm{g}\right.$ novobiocin per disc). $8325 \mathrm{Spc}^{\mathrm{R}}$ was isolated similarly with $40 \mu \mathrm{g}$ spectinomycin per disc. 8325 ade, 8325 gua and 8325 pur were isolated after EMS mutagenesis by replica plating colonies grown on complete PN medium (Pattee \& Neveln, 1975) to PN medium lacking adenine, guanine or both. 8325 thy was a thymidine-requiring derivative obtained by the method of Stacey \& Simson (1965). All mutants were isolated by H. Hackling \& K. G. H. Dyke (unpublished).

Maintenance and growth of cultures. Strain 8325 was maintained on CY agar (Novick, 1963). For $8325 \mathrm{Nov}^{\mathrm{R}}$ 
this was supplemented with $5 \mu \mathrm{g}$ novobiocin $\mathrm{ml}^{-1}$; for $8325 \mathrm{Spc}^{\mathrm{R}}$, with $200 \mu \mathrm{g}$ spectinomycin $\mathrm{ml}^{-1} .8325$ thy was maintained on Difco AOAC defined medium agar with $10 \mu \mathrm{g}$ thymidine $\mathrm{ml}^{-1} ; 8325$ ade, 8325 gua and 8325 pur were maintained on CY agar. Bacteria were normally grown in CY medium (Novick, 1963) at $30{ }^{\circ} \mathrm{C}$. Inocula from agar stock plates were grown for 15 to $18 \mathrm{~h}$ and then diluted into fresh, warmed medium and grown into exponential phase.

Bacteriophage. Phage 53 of the International Phage Typing Series was used.

Propagation of bacteriophages. CY medium $(5 \mathrm{ml}$ ) was mixed with $10 \mathrm{ml}$ of phage buffer (Novick, 1963), and then bacteria [final density about $5 \times 10^{7}$ colony-forming units (c.f.u.) $\mathrm{ml}^{-1}$ ] and phage 53 were added to give an input ratio of about 0.5 . Incubation with gentle shaking, at $30^{\circ} \mathrm{C}$, was continued until the medium cleared; then more bacteria were added to give $2 \cdot 5 \times 10^{8}$ c.f.u. $\mathrm{ml}^{-1}$ and incubation was continued until the medium cleared again. The resultant phage preparation contained $3 \times 10^{9}$ to $5 \times 10^{9}$ plaque-forming units (p.f.u.) $\mathrm{ml}^{-1}$; contaminating bacteria were removed by passage through a sterile $24 \mathrm{~mm}$ Millipore filter $(0.45 \mu \mathrm{m}$ pore size $)$.

Transduction. A $15 \mathrm{~h}$ culture of recipient bacteria was diluted to give about $5 \times 10^{8}$ c.f.u. $\mathrm{ml}^{-1}$ in $20 \mathrm{ml}$ of CY medium. After incubation at $30^{\circ} \mathrm{C}$ for $1 \mathrm{~h}$, the bacteria were harvested by centrifugation and resuspended in $2 \mathrm{ml}$ of warmed CY medium and $4 \mathrm{ml}$ of phage buffer. The suspension was divided into two, and $0.1 \mathrm{ml}$ of transducing phage preparation was added (input ratio 0.01 to 0.05 ) to one half. Both suspensions were then incubated at $30^{\circ} \mathrm{C}$ with gentle shaking for $30 \mathrm{~min}$ to allow phage adsorption. Sodium citrate (final concentration $0.4 \mathrm{M}$ ) was then added, to prevent further phage adsorption, and the suspension was centrifuged. After washing with CY medium (plus $0.2 \mathrm{M}$-sodium citrate) and recentrifuging, the bacteria were finally resuspended in CY medium (plus $0 \cdot 2 \mathrm{M}$-sodium citrate) and incubated for a further 2 to $3 \mathrm{~h}$ at $30^{\circ} \mathrm{C}$ with aeration to allow phenotypic expression of transduced genes; they were then plated on selective plates. The bacterial suspension without transducing phage was a control for contaminants which might grow on the selective plates. In addition $0 \cdot 1 \mathrm{ml}$ samples of transducing phage preparations were always plated to check for contamination.

Mutagenesis and selection of mutants temperature-sensitive for growth. EMS mutagenesis was carried out according to Novick (1963). Bacteria grown into stationary phase after mutagenesis were diluted into fresh medium, grown into exponential phase at $30^{\circ} \mathrm{C}$ and plated on $\mathrm{CY}$ agar to give approximately 100 colonies per plate. Incubation at $30^{\circ} \mathrm{C}$ was continued until colonies were about $0.5 \mathrm{~mm}$ in diameter $(18 \mathrm{~h})$; then, after marking the position of all visible colonies, the plates were transferred to $42{ }^{\circ} \mathrm{C}$. After 6 to $8 \mathrm{~h}$ colonies able to grow at $42^{\circ} \mathrm{C}$ were large; colonies remaining small were picked and tested for temperature-sensitivity by streaking on plates at 42 and $30^{\circ} \mathrm{C}$.

Incorporation of radioactively labelled precursors. To measure the incorporation' of 'radioactively labelled precursors into macromolecules, $1.0 \mathrm{ml}$ samples of cultures of bacteria growing in the presence of these precursors were removed and mixed with an equal volume of ice-cold $10 \%(\mathrm{w} / \mathrm{v})$ trichloroacetic acid (TCA). After $30 \mathrm{~min}$ at $0^{\circ} \mathrm{C}$, the samples were filtered on to $2 \cdot 1 \mathrm{~cm} \mathrm{GF} / \mathrm{C}$ discs (Whatman), washed with $4 \times 5 \mathrm{ml}$ ice-cold $5 \%(\mathrm{w} / \mathrm{v}) \mathrm{TCA}$ and $4 \times 5 \mathrm{ml}$ ethanol, and dried at $80^{\circ} \mathrm{C}$ under reduced pressure. The radioactivity in each sample was determined in a liquid scintillation counter after addition of $2.5 \mathrm{ml}$ of $5 \%(\mathrm{w} / \mathrm{v}) 2-\left(4^{\prime}-\right.$ tert-butylphenyl)-5-(4"-biphenylyl)-1,3,4-oxadiazole (butyl-PBD) in toluene.

\section{RESULTS}

\section{Isolation of temperature-sensitive mutants with defects affecting DNA replication}

After EMS mutagenesis, approximately $10^{6}$ colonies were screened and 96 mutants that were temperature-sensitive for growth were isolated. A group of 80 of these mutants was screened for defects in DNA synthesis by a rapid method based on that of Karamata \& Gross (1970): incorporation of $\left[{ }^{3} \mathrm{H}\right]$ thymidine and $\left[{ }^{14} \mathrm{C}\right]$ phenylalanine was measured at $42{ }^{\circ} \mathrm{C}$ to determine whether DNA synthesis was more defective than protein synthesis at this temperature. The other 16 mutants were screened by an analogous method measuring incorporation in parallel cultures of $\left[{ }^{3} \mathrm{H}\right]$ thymidine and $\left[{ }^{3} \mathrm{H}\right]$ uracil at 30 and $42{ }^{\circ} \mathrm{C}$. The first group yielded 11 putative Dna mutants and the second, three. Further investigation of incorporation of phenylalanine, glycine, glycerol, uracil and thymidine by these mutants, as measures of biosynthesis of protein, protein and cell wall, membrane, RNA and DNA, respectively, was carried out at 30 and $42{ }^{\circ} \mathrm{C}$. On the basis of (i) normal incorporation of these precursors at $30^{\circ} \mathrm{C}$ with the wild type (WT) as control, (ii) primary defects only in thymidine incorporation at $42{ }^{\circ} \mathrm{C}$, and (iii) sustained viability on agar plates at $30^{\circ} \mathrm{C}$, four mutants were selected for further study, three from the first group (ts 39, ts 53 and ts 70 ) and 
Table 1. Rate of incorporation of radioactively labelled precursors of macrcmolecules into 8325WT and temperature-sensitive mutants at 30 and $42{ }^{\circ} \mathrm{C}$

\begin{tabular}{|c|c|c|c|c|c|}
\hline \multirow[b]{2}{*}{$\begin{array}{l}\text { Strain and } \\
\text { temperature }\end{array}$} & \multicolumn{5}{|c|}{$10^{-3} \times$ Rate of incorporation (c.p.m. per $\left.A_{67 \overline{\mathrm{nm}}}^{1 \mathrm{~cm}}=2 \cdot 5\right)^{*}$} \\
\hline & $\begin{array}{c}{\left[\mathrm{U}^{14} \mathrm{C}\right]-} \\
\text { Phenylalanine }\end{array}$ & $\begin{array}{l}{\left[2-{ }^{3} \mathrm{H}\right]-} \\
\text { Glycine }\end{array}$ & $\begin{array}{c}{\left[2-^{3} \mathrm{H}\right]-} \\
\text { Glycerol }\end{array}$ & $\begin{array}{l}{\left[5-{ }^{3} \mathrm{H}\right]-} \\
\text { Uracil }\end{array}$ & $\begin{array}{c}{\left[6-{ }^{3} \mathrm{H}\right]-} \\
\text { Thymidine }\end{array}$ \\
\hline WT $30^{\circ} \mathrm{C}$ & 6 & 60 & 35 & 45 & 90 \\
\hline $42^{\circ} \mathrm{C}$ & 6 & 50 & 30 & 35 & 80 \\
\hline ts $3930^{\circ} \mathrm{C}$ & 6 & 40 & 30 & 45 & 70 \\
\hline $42{ }^{\circ} \mathrm{C}$ & 6 & 50 & 40 & 40 & $37 \cdot 5+5$ \\
\hline ts $5330^{\circ} \mathrm{C}$ & $6 \cdot 3$ & 40 & 20 & 50 & 100 \\
\hline $42^{\circ} \mathrm{C}$ & $6 \cdot 5$ & 40 & 25 & 40 & 10 \\
\hline ts $7030^{\circ} \mathrm{C}$ & 5 & 50 & 35 & 60 & 70 \\
\hline $42{ }^{\circ} \mathrm{C}$ & 5 & 60 & 40 & $45 \dagger 15 \ddagger$ & 10 \\
\hline ts $1130^{\circ} \mathrm{C}$ & 5 & 80 & 60 & 10 & 90 \\
\hline $42^{\circ} \mathrm{C}$ & 5 & 60 & 40 & 8 & 1 \\
\hline
\end{tabular}

* Precursors were present at the following activities and concentrations: $\left[\mathrm{U}-{ }^{14} \mathrm{C}\right]$ phenylalanine, $0.1 \mu \mathrm{Ci}$ $\mathrm{ml}^{-1}, 50 \mu \mathrm{g} \mathrm{ml}^{-1}$; [2- $\left.{ }^{3} \mathrm{H}\right]$ glycine, $1 \mu \mathrm{Ci} \mathrm{ml}^{-1}, 100 \mu \mathrm{g} \mathrm{ml}^{-1}$; [2- $\left.{ }^{3} \mathrm{H}\right]$ glycerol, $2 \cdot 5 \mu \mathrm{Ci} \mathrm{ml}^{-1}$, no exogenous source other than in $\mathrm{CY}$ medium; $\left[5-{ }^{3} \mathrm{H}\right]$ uracil, $1 \mu \mathrm{Ci} \mathrm{ml}^{-1}$, no exogenous source other than in $\mathrm{CY}$ medium; [6- $\left.{ }^{3} \mathrm{H}\right]$ thymidine, $1 \mu \mathrm{Ci} \mathrm{ml}^{-1}, 10 \mu \mathrm{g} \mathrm{ml}^{-1}$.

$\dagger$ Initial rate. $\ddagger$ Final rate.

one from the second (ts11). Table 1 shows the rates of incorporation of these precursors by $8325 \mathrm{WT}$ and the four derived temperature-sensitive strains, at 30 and $42{ }^{\circ} \mathrm{C}$. All five strains showed similar rates of incorporation of phenylalanine, glycine and glycerol per unit increase in absorbance. WT, ts 39 and ts 53 incorporated uracil at similar rates at 30 and $42{ }^{\circ} \mathrm{C}$ while ts 70 showed a decreasing rate of uracil incorporation at $42^{\circ} \mathrm{C}$, although incorporation was normal at $30^{\circ} \mathrm{C}$. This defect at $42^{\circ} \mathrm{C}$, however, appeared after the defect observed in DNA synthesis (see below) and was much smaller. ts11 showed normal uracil incorporation during rapid screening but in further tests uracil incorporation was poor, compared with WT, at both 30 and $42^{\circ} \mathrm{C}$. However, since the mean generation time at $30^{\circ} \mathrm{C}$ was 90 min compared with about $48 \mathrm{~min}$ for WT, uracil incorporation could be correlated with growth rate assuming that RNA represents a lower proportion of the dry weight at lower growth rates. In support of this explanation is the observation that with subculturing over about 6 months the mean generation time decreased to about $51 \mathrm{~min}$, and uracil incorporation became the same as in WT. These variations did not affect DNA synthesis.

The characteristics of thymidine incorporation per unit increase in absorbance by these strains are shown in Fig. 1. The incorporation by all strains was similar at $30^{\circ} \mathrm{C}$. ts 39 showed considerable residual incorporation after transfer to $42^{\circ} \mathrm{C}$, but ts 53 , ts 70 and ts 11 all showed a rapid reduction in the rate of incorporation under these conditions. To test that this reduced incorporation was not due to defective uptake of thymidine at $42{ }^{\circ} \mathrm{C}$, DNA was estimated by the method of Burton (1956). Typical results are shown in Fig. 2. These confirmed that DNA synthesis in the temperature-sensitive strains was reduced at $42{ }^{\circ} \mathrm{C}$ but normal at $30^{\circ} \mathrm{C}$. ts 39 did not show a significant reduction in the rate of DNA synthesis at $42{ }^{\circ} \mathrm{C}$ until about $30 \mathrm{~min}$ after transfer, by which time the DNA content had almost doubled. After about $90 \mathrm{~min}$ the DNA content had increased by 150 to $200 \%$. The amount of DNA synthesized in ts 39 was not significantly reduced by transfer to $44^{\circ} \mathrm{C}$ instead of $42^{\circ} \mathrm{C}$. In ts53, DNA synthesis showed a reduced exponential rate on transfer to $42{ }^{\circ} \mathrm{C}$ and the DNA content increased by about $90 \%$ in $90 \mathrm{~min}$. ts 70 and ts 11 showed virtually no increase in DNA for about $45 \mathrm{~min}$ after transfer to $42{ }^{\circ} \mathrm{C}$, but subsequently there was some increase in DNA content.

It was concluded that ts53, ts70 and ts 11 probably have defects either in elongation enzymes or in precursor synthesis. The properties of ts 39 cannot easily be explained either 


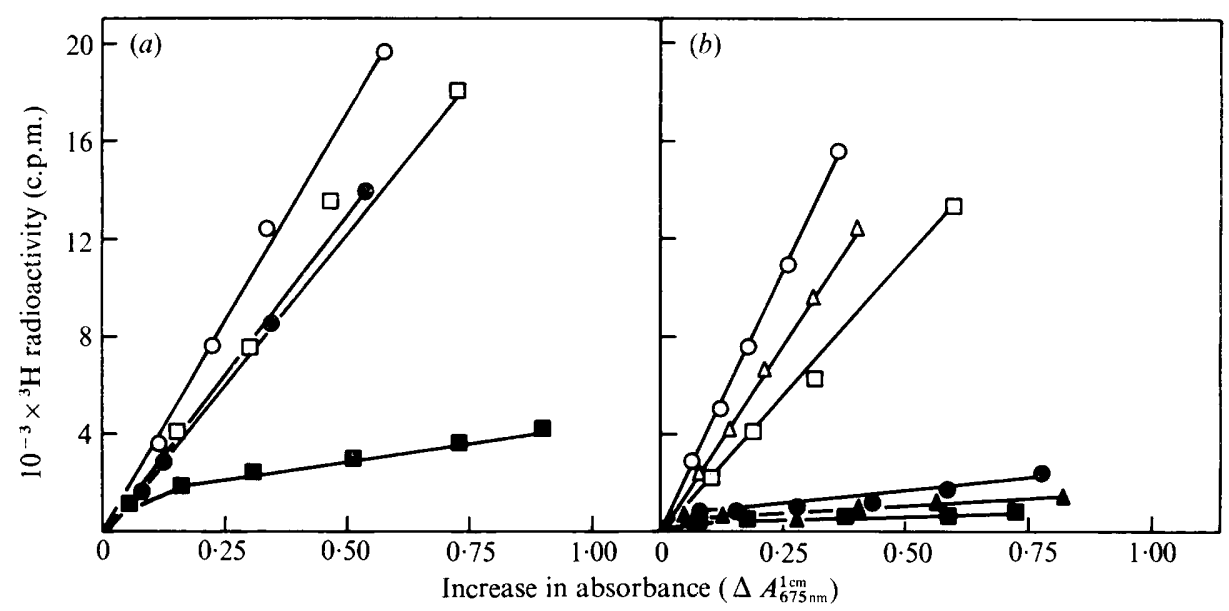

Fig. 1. Incorporation of $\left[6-{ }^{3} \mathrm{H}\right]$ thymidine into $8325 \mathrm{WT}$, ts 39 , ts 53 , ts 70 and ts 11 . Cultures $(15 \mathrm{~h})$ of these strains were diluted into fresh, warmed CY medium containing $10 \mu \mathrm{g}$ thymidine $\mathrm{ml}^{-1}$ and grown into exponential phase at $30^{\circ} \mathrm{C}$. The cultures were then diluted to about $A_{675 \mathrm{~nm}}^{11 \mathrm{~cm}}=0.1$ in the same medium, and $\left[6^{-3} \mathrm{H}\right]$ thymidine (final concn $1 \mu \mathrm{Ci} \mathrm{ml}{ }^{-1}$ ) was added. Incorporation and $A_{675 \mathrm{~nm}}^{1 \mathrm{~cm}}$ at 30 and $42^{\circ} \mathrm{C}$ were then determined periodically for between 90 and $120 \mathrm{~min}$. Incorporation at $30^{\circ} \mathrm{C}$ (open symbols) and $42^{\circ} \mathrm{C}$ (closed symbols): $(a) \bigcirc, 0, \mathrm{WT} ; \square, \mathbf{\square}$, ts $39 ;(b) \bigcirc, \bigcirc$, ts 53 ; $\square, \boldsymbol{\square}$, ts $70 ; \triangle, \Delta$, ts11. (The mean generation time of WT at $42{ }^{\circ} \mathrm{C}$ was 26 min.)

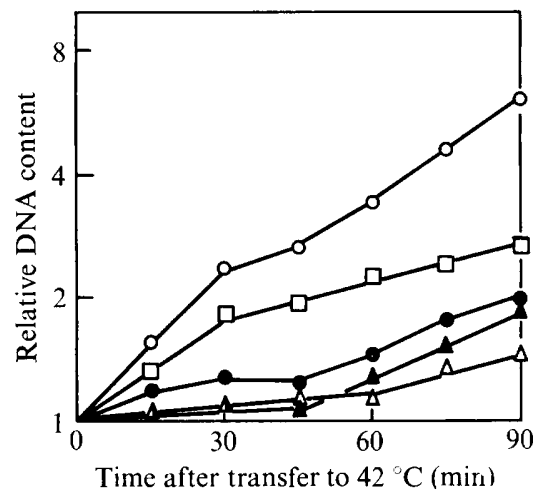

Fig. 2. DNA synthesized by $8325 \mathrm{WT}$, ts 39 , ts 53 , ts 70 and ts 11 after transfer to $42{ }^{\circ} \mathrm{C}$ as estimated by the method of Burton (1956). Cultures $(15 \mathrm{~h})$ were diluted into fresh, warmed CY medium and grown into exponential phase at $30^{\circ} \mathrm{C}$. The cultures were then diluted to about $A_{675 \mathrm{~nm}}^{1 \mathrm{~cm}}=0 \cdot 25$ and transferred to $42^{\circ} \mathrm{C}$. Samples $(10 \mathrm{ml})$ were withdrawn every $15 \mathrm{~min}$ for $90 \mathrm{~min}$ and their DNA contents were determined. $O$, WT; $\square$, ts 39; $\odot$, ts53; $\triangle$, ts $70 ; \Delta$, ts11.

in this way or by supposing it is an initiation-defective mutant, since the residual synthesis after transfer to $42{ }^{\circ} \mathrm{C}$ is too extensive to result simply from completion of rounds of replication likely to have been already initiated at $30^{\circ} \mathrm{C}$ under these conditions (Sueoka \& Yoshikawa, 1965). Possible explanations include defects in synthesis of new replication complexes or temperature-sensitive termination of chromosome replication.

Transduction analysis of the mutations in ts $39, \mathrm{ts} 53, \mathrm{ts} 70$ and ts 11

The frequencies of reversion to temperature-stability of ts 11 and ts70 were low (about 1 in $\left.10^{8}\right)$. ts 39 and ts 53 had higher reversion frequencies ( 1 in $10^{6}$ for ts $53 ; 1$ in $5 \times 10^{6}$ for ts39); moreover, when $10^{6}$ to $10^{7}$ bacteria were spread on a plate, in addition to the revertants a large number of tiny, slow-growing colonies appeared. Since the frequency of 
Table 2. Linkage of nov to the ts53, ts 70 and ts 11 mutations

\begin{tabular}{ccc}
$\begin{array}{c}\text { Transductional } \\
\text { recipient* }\end{array}$ & $\begin{array}{c}\text { Fraction of novobiocin- } \\
\text { resistant transductants that } \\
\text { were temperature-stable }\end{array}$ & $\begin{array}{c}\text { Fraction of temperature-stable } \\
\text { transductants that were } \\
\text { novobiocin-resistant }\end{array}$ \\
ts11 & $52 / 115(45 \%)$ & $94 / 138(68 \%)$ \\
ts70 & $58 / 124(47 \%)$ & $94 / 143(66 \%)$ \\
ts53 & $49 / 92(53 \%)$ & ND \\
ts39 & $0 / 93(0 \%)$ & ND \\
\multicolumn{4}{c}{ ND, Not done. } \\
* Donor was phage 53 propagated on $8325 \mathrm{Nov}^{\mathrm{R}}$.
\end{tabular}

transduction of chromosomal genes in $S$. aureus is quite low $\left(<1\right.$ in $10^{6}$ ), only ts70 and ts 11 were suitable as recipients in transduction analysis of the temperature-sensitive mutations.

Transducing phage preparations, propagated on WT, ts 39 , ts53, ts70 and ts 11 , were used to transduce temperature-stability into ts 70 or ts 11 . Initial experiments showed that phage propagated on ts 39 gave as many temperature-stable transductants as phage propagated on WT. The controls of phage propagated on ts70 into ts 70 (recipient) or phage propagated on ts 11 into ts 11 (recipient) gave about $1 \%$ of this number. Phage propagated on ts 53 or ts 11 into ts 70 (recipient) or phage propagated on ts 53 and ts70 into ts 11 (recipient) gave 1 to $10 \%$, and the numbers obtained were not significantly different from the number of revertants obtained on control plates. It was tentatively concluded that the ts 53 , ts 70 and ts 11 mutations were clustered and that ts 39 was at least $1 \%$ of the chromosome away (a minimum estimate of the amount of DNA likely to be carried by the transducing phage). Alternatively the results could be explained by supposing that the different phage preparations, although having similar titres of p.f.u. $\mathrm{ml}^{-1}$, differed in efficiency of transduction.

To check this a genetic marker linked by transduction to the ts 53 , ts 70 and ts 11 mutations was sought. By using as a donor a novobiocin-resistant mutant of $8325 \mathrm{WT}$, we found that a gene conferring resistance to novobiocin (nov) was about $50 \%$ cotransduced with these three mutations (Table 2). However, when a phage preparation propagated on $8325 \mathrm{Nov}^{\mathrm{R}}$ was used to transduce novobiocin resistance into ts 39 , none of the transductants was temperature-stable. These results confirm that the ts53, ts 70 and ts 11 mutations are close together and not linked to the mutation in ts 39 . They cannot, however, eliminate the possibility that the gene conferring novobiocin resistance separates one of the three Dna mutations from the other two.

We settled this point in the following way. Novobiocin resistance was transduced into ts 11 , ts 53 and ts 70 and novobiocin-resistant strains which were still temperature-sensitive were selected. Phage propagated on each and on $8325 \mathrm{Nov}^{\mathrm{R}}$ were used to transduce either temperature stability or novobiocin resistance into ts 11 or ts 70 (Table 3). Although the frequency of transduction to novobiocin resistance was much the same for all four phage preparations, the frequency of temperature-stable transductants with phage propagated on ts $11 \mathrm{Nov}^{\mathrm{R}}$, ts $70 \mathrm{Nov}^{\mathrm{R}}$ or ts $53 \mathrm{Nov}^{\mathrm{R}}$ was reduced by at least $95 \%$ compared with the frequency with phage propagated on $8325 \mathrm{Nov}^{\mathrm{R}}$, and those few colonies that were found may be revertants rather than transductants. It was concluded that the mutations in ts53, ts70 and ts 11 are all closely clustered on one side of the nov locus.

Similar transductional analysis with phage propagated on $8325 \mathrm{Spc}^{\mathrm{R}}, 8325$ thy, 8325 ade, 8325 gua or 8325 pur failed to show any linkage of these loci with ts53, ts 70 and ts $11 \mathrm{mu}$ tations. 
Table 3. Average number of transductants per plate when phage 53 propagated on $8325 \mathrm{Nov}^{\mathrm{R}}$ or temperature-sensitive mutants of $8325 \mathrm{Nov}^{\mathrm{R}}$ was used to transduce novobiocin resistance or temperature stability into ts 70 or ts 11 in the same experiment

$\begin{array}{ccccc}\begin{array}{c}\text { Transducing phage 53 } \\ \text { propagated on donor strain : }\end{array} & \begin{array}{c}\text { Temperature } \\ \text { stability }\end{array} & \begin{array}{c}\text { Novobiocin } \\ \text { resistance }\end{array} & \overbrace{\begin{array}{c}\text { Temperature } \\ \text { stability }\end{array}}^{\text {ts11 }} \\ \text { 8325 Nov } & \begin{array}{c}\text { Novobiocin } \\ \text { resistance }\end{array} \\ \text { ts70 Nov } & 115 & 50 & 86 & 100 \\ \text { ts11 Nov } & 1 & 50 & 4 & 195 \\ \text { ts53 Nov } & 4 & 60 & 1 & 150 \\ \text { Control (no phage 53) }^{\mathbf{R}} & 3 & 34 & 6 & 100 \\ & 6 & 0 & 5 & 0\end{array}$

\section{DISCUSSION}

On the basis of both phenotypic and genetic characterization the four mutants tested fall into two groups. The mutation in ts 39 , which is not genetically linked to the mutations in the other mutants, has a phenotype which falls into neither of the classical dna mutant categories of elongation or initiation-defective (Hirota, Ryter \& Jacob, 1968). The considerable residual DNA synthesis after transfer to $42{ }^{\circ} \mathrm{C}$ (150 to $200 \%$ increase) is much greater than the 30 to $40 \%$ expected for an initiation-defective mutant with a pair of replication forks on each chromosome (Sueoka \& Yoshikawa, 1965). An increase of the order of $200 \%$ would be expected if there were about 30 replication forks evenly distributed on each chromosome. Possible explanations for the phenotype may be defects in the synthesis of replication elongation sites or a defect in termination of replication.

ts 11 , ts 53 and ts 70 all contain temperature-sensitive defects which are very rapidly expressed on transfer to $42^{\circ} \mathrm{C}$, and the mutations in these mutants are close together on the chromosome. It is remarkable that three out of the four mutations studied should show such close linkage. It may be chance, but another explanation might be that this is a mutational hot spot. It is interesting that in studies of dna loci in Escherichia coli, mutations at certain loci have been isolated in much greater numbers than at others (Wechsler \& Gross, 1971); out of five dna mutants isolated and studied by Kohiyama (1968), two were dnaA mutants.

Alternatively there may be a cluster of dna genes in this region. Such an explanation would be plausible if the nov locus linked to these Dna mutations conferred resistance through alteration of a gene product involved directly in DNA replication. Novobiocin is known to be a selective inhibitor of DNA replication in E. coli (Smith \& Davies, 1967; Standenbauer, 1975) and the site of action of novobiocin has been shown to be a DNA gyrase enzyme (Gellert et al., 1976). However, resistance to novobiocin may also result from altered permeability to the drug; the above linkage might therefore be fortuitous. The explanation must await further investigation of the nature of resistance ro novobiocin conferred by the nov gene used here.

Examination of previous transductional mapping in S. aureus (Ritz \& Baldwin, 1962; Pattee et al., 1974) allows an estimation of the separation of the ts 11 , ts 53 and ts 70 mutations from each other and from the nov locus. It appears that the ts 11 , ts 53 and ts 70 mutations may all be in the same gene although crossover can occur between the mutations, and that this gene may be four to five genes away from the nov locus. The locus containing the ts 11 , ts53 and ts70 mutations has been tentatively designated $d n a A$.

Previously, in $S$. aureus, transductional linkage has been demonstrated between genes in the same operon (Ritz \& Baldwin, 1962; Kloos \& Pattee, 1965; Tien \& White, 1968; Barnes, Bondi \& Fuscaldo, 1971) and between functionally related cistrons (Pattee et al., 
1974). The addition of dna loci to the genetic map of $S$. aureus is useful, especially because some mutants show reversion frequencies which should allow them to be used in transformation mapping as well. If the nov locus is the same as that used by Pattee \& Neveln (1975) in transformational analysis then, tentatively, we can place this dnaA locus between hisGb15 and nov or between nov and pur-102. The finding that dnaA is not linked by transduction to ade, gua or pur does not necessarily indicate a position between hisGb15 and nov since either these purine auxotrophs may not be at the pur-102 region (another pur locus exists) or the distance between nov and pur-102 may be too great to show linkage of dnaA to both.

C. M. Thomas was the holder of an M.R.C. Studentship for training in research methods during the course of this research.

\section{REFERENCES}

Barnes, I. J., Bondi, A. \& Fuscaldo, K. E. (1971). Genetic analysis of lysine auxotrophs of Staphylococcus aureus. Journal of Bacteriology 105, 553555.

Burton, K. (1956). A study of the conditions and mechanism of the diphenylamine reaction for the colorimetric estimation of DNA. Biochemical Journal 62, 315-323.

Gellert, M., O’Dea, M. H., ItoH, T. \& Tomizawa, J-I. (1976). Novobiocin and coumermycin inhibit DNA supercoiling catalysed by DNA gyrase. Proceedings of the National Academy of Sciences of the United States of America 73, 4474-4478.

Hirota, Y., RYTER, A. \& JACOB, F. (1968). Thermosensitive mutants of $E$. coli affected in the processes of DNA synthesis and cellular division. Cold Spring Harbor Symposia on Quantitative Biology 33, 677-693.

Karamata, D. \& Gross, J. D. (1970). Isolation and genetic analysis of temperature-sensitive mutants of B. subtilis defective in DNA synthesis. Molecular and General Genetics 108, 277-287.

Kloos, W. E. \& Pattee, P. A. (1965). Transduction analysis of the histidine region in Staphylococcus aureus. Journal of General Microbiology 39, 195207.

Kohiyama, M. (1968). DNA synthesis in temperature-sensitive mutants of E. coli. Cold Spring Harbor Symposia on Quantitative Biology 33, 317324.

Measures, J. C. (1973). The relationships between the protoplast membrane and deoxyribonucleic acid in Staphylococcus aureus. D.Phil. thesis, University of Oxford.

Novick, R. P. (1963). Analysis by transduction of mutations affecting penicillinase formation in Staphylococcus aureus. Journal of General Microbiology 33, 121-136.

Novick, R. P. (1967). Mutations affecting maintenance and replication of penicillinase plasmids in Staphylococcus aureus. Proceedings of the 5th Congress of Chemotherapy, Vienna, 269-273.

Novick, R. P. (1974). Studies on plasmid replication. III. Isolation and characterization of replicationdefective mutants. Molecular and General Genetics 135, 131-147.
Novick, R. P., Wyman, L., Bouanchand, D. \& MurPhy, E. (1974). Plasmid life cycles in Staphylococcus aureus. In Microbiology-1974, pp. 115129. Edited by D. Schlessinger. Washington, D.C.: American Society for Microbiology.

Pattee, P. A. \& Neveln, D. S. (1975). Transformation analysis of three linkage groups in Staphylococcus aureus. Journal of Bacteriology 124, 201211.

Pattee, P. A., Schutzbank, T., Kay, H. D. \& Laughlin, M. H. (1974). Genetic analysis of the leucine biosynthetic genes and their relationship to the ilv gene cluster. Annals of the New York Academy of Sciences 236, 175-186.

RAFTERY, S. (1974). Studies on staphylococcal DNA. M.Sc. thesis, University of Oxford.

RitZ, H. L. \& BALDwin, J. N. (1962). A transductional analysis of complex loci governing the synthesis of tryptophan by Staphylococcus aureus. Proceedings of the Society for Experimental Biology and Medicine 110, 667-671.

Smith, D. H. \& Davies, B. D. (1967). Mode of action of novobiocin in Escherichia coli. Journal of Bacteriology 93, 71-79.

StaCEY, K. A. \& Simson, E. (1965). Improved method for the isolation of thymine-requiring mutants of Escherichia coli. Journalof Bacteriology 90, 554-555.

STANDENBAUER, W. L. (1975). Novobiocin - a specific inhibitor of semiconservative DNA replication in permeabilized Escherichia coli cells. Journal of Molecular Biology 96, 201-205.

Sueoka, N. \& Yoshikawa, H. (1965). The chromosome of Bacillus subtilis. I. The theory of marker frequency analysis. Genetics 52, 747-757.

TIEN, W. \& WhITE, D. C. (1968). Linear sequential arrangement of genes for the biosynthetic pathway of protoheme in Staphyloccocus aureus. Proceedings of the National Academy of Sciences of the United States of America 61, 1392-1398.

WeChSLER, J. A. \& Gross, J. D. (1971). Escherichia coli mutants temperature-sensitive for DNA synthesis. Molecular and General Genetics 113, 273-284. 